\title{
TO BE DIFFERENT
}

\section{P. COMPAAN*}

\section{SUMMARY}

Society (including health professionals) ascribes inferiority to the disabled in interaction, be it consciously or unconsciously, thus further complicating a difficult new situation, physically and psychologically. Examples are cited. A plea is made for more emphasis on psychosocial rehabilitation early on.

Society determines whether some individuals should be regarded as different by selecting certain facets of their being, and attaching to these facets degrading labels and interpretations.

Example. Because you are in a wheelchair, you look different, and because you look different, I am going to HANDLE you differently.

Many times this HANDLING is by placing a person in an inferior status position: degrading him!

In many cases, ascription of difference represents a slowly developing process beginning with a traumatic experience in a person's life and resulting in hospitalisation for many months.

By repetition at every occasion of direct and indirect interaction, people weave a pattern of inferiority, ostensibly covering the whole of the individual. This may happen consciously or unconsciously. Professional people in hospital thus participate in the difference input process and mould the course of the disabled person's life.

Becoming disabled and finding oneself in a wheelchair, alters a person's life situation not only with respect to what he can or cannot do physically whicl is often the major focus of the rehabilitation personnel - but also with respect to the social interaction with others.

The newly disabled person KNOWS that he is the same person that he was before the injury to his body occurred. Yet, he is so frequently and persistently placed in inferior status positions by his professional "helpers" that, in time, he is coerced into wondering if he has become a different kind of person.,

The whole illness and disability experience places him in new psychological situations where his customary behaviour may stimulate responses so radically different from that he is accustomed to, that he may often, consciously or unconsciously, question who he is, what roles are appropriate for him, and what he can expect to be able to do.

The earliest and possibly the critical answers to such identity and role questions come from the hospital personnel in the everyday situations during treatment. These answers are more often subtle and nonverbal. It makes explicit the probability that the patient may have to adjust to being a second class citizen faced not only with physical obstacles, but also with social devaluation. It teaches him that as society views him, he is no longer a responsible, employable adult ... but psychologically and sociologically a child.

+ Talk given on 27 April 1981 in the Auditorium at the Physiotherapy College, Pretoria.

* Quadriplegic.

Received 17 August 1981.

\section{OPSOMMING}

Die gemeenskap (insluitende gesondheidspersoneel) skryf minderwaardigheid aan die gestremde toe tydens interaksie, bewustelik of onbewustelik, wat dan ' $n$ moeilike nuwe situasie, fisies en psigologies, verder kompliseer. Voorbeelde word gegee. 'n Pleidooi word gelewer vir meer klem op vroee psigososiale rehabilitasie.

\section{Some common examples}

Wheeling down the corridor an attendent/nurse hustle alongside and challengingly or even sarcastically say: "Hey, where do you think you're going?" or "You're not supposed to be here go to your room."

- Getting your wheelchair hijacked by somebody without comment, and being wheeled to the dining. room.

- Staff meetings, where the patient is supposed to participate in his rehabilitation, are held without him.

- When patients enquire about why some therapeutic procedure is being employed, it is not uncommon for them to be told: "It is good for you" or "Doctor's orders."

Perhaps the most common way of telling the patient that he is a machine in the shop for repair is the habit of communicating with the person pushing the wheelchair, instead of with the patient himself. The patient finds himself sandwiched between two white coats with the one asking the other: "Now where does she go?"

It can be asserted that the job of proper rehabilitation of patients is impossible without giving full cognizance to the impelling psychosocial problems that they face.

It is regrettable that treatment of persons with such conditions should have become fixed within an essentially medical, rather than a more general rehabilitative mode because, except for the initial period and for the subsequent maintenance of good physical health, the predominant problems are:

- emotional

- interpersonal

- functional

- vocational

AND in that order!

Now, lest physicians and other medical persons directly involved, become offended at this point, let it be understood that when the term 'psychosocial' is used, it does not refer to the activities and concern of any particular profession. It refers to the perceptions of the patient, of himself and of his immediate and extended interpersonal environment, which should be understood and responded to by all personnel, professional and non-professional alike.

The focus of rehabilitation should be to assist the person toward reformulating a self that approves of continuing to be, the promotion of a new self-image predicated on worth, ego-integrity and self-esteem, rather than on deficiency and self-contempt.

Early rehabilitation should include facilitation of a restitutive orientation so that recrystallisation of the self is in terms of acceptance, rather than hate. The direction of this recrystallisation will be a major determinant of response to later specific rehabilitation procedures. Rejection of aids by quadriplegics well 
illustrates the consequences of resolution of the self in the direction of hate.

The nebulous phrase 'acceptance of loss' might be defined as being the extent to which the reconstituted self is oriented towards self approval and responsive to reality.

Some persons are restitutively oriented following disablement, attempting to compensate for their condition. Others are not directed towards positive gratifications, seeking instead avoidance of the implications of their condition, and their primary motivation is to ward off anxiety, shame and other noxious effects. This latter resolution is the basis for residual self-hate.

Professional people should extend every aid possible to help the patient feel that he, as a personality, still continues.

The obligation to give functional aid should be seen in the larger context of enhancing self-respect. $\mathrm{My}$ fear is that the emphasis on function serves as a readv way of avoiding the affective implications of disable ment.

This year is the INTERNATIONAL YEAR OF DISABLED PERSONS (and I put the emphasis on persons) and now is the time to put things right in your own mind and also in the so-called rehabilitation centres.

I did not choose the topic of the attitude of the public towards disabled persons because I firmly believe that once a disabled person has learned that his disability is irrelevant for the attainment of some of his more basic goals, he will find the attitude of the public not'such a great obstacle.

\section{Bibliography}

Social and Psychological Aspects of Disability (1978). Second Edition. Edited by Joseph Stubbins Ph. D. University Park Press. 